\title{
TIME-VARYING RELATIONSHIP BETWEEN INTERNATIONAL TRADE AND INTERNATIONAL TOURISM IN TURKEY ${ }^{1}$
}

\author{
TÜRKIYE'DE ULUSLARARASI TİCARET VE ULUSLARARASI TURIZZM \\ ARASINDAKİ ZAMANLA DEĞİSEN İLIŞKİLER \\ Mustafa KIRCA ${ }^{2}$ - Mustafa ÖZER ${ }^{3}$
}

\begin{abstract}
In this paper we examine the causal relations between international tourism demand and total exports and its subcomponents (intermediate goods and capital goods) and total imports (intermediate goods and capital goods) in Turkey by using Hacker and Hatemi-J Bootstrap Toda-Yamamoto and Time-Varying Causality tests. The results of the study indicate the causal relations between international tourism demand and exports and imports. The results also indicate that these causal relations between international tourism demand and international trade are not stable. In other words, they have a time-varying nature. Moreover, international tourism demand's contribution to imports is greater than that of exports. Finally, the international tourism demand is more often affected by components of exports and imports and the signs of those effects are generally positive. Thus, policy makers, sector representatives and market professionals related to both international trade and tourism should take into account of this time-varying nature of causal relations between these variables before implementing policies aiming to promote both.
\end{abstract}

Keywords: International Tourism Demand, International Trade, Hacker and Hatemi-J Bootstrap Toda-Yamamoto Test, Time-Varying Causality Test.

Jel Classification: C22, F14, Z32

$\ddot{O} z$

$\mathrm{Bu}$ çalışmada Türkiye'de uluslararası turizm talebi ve toplam ihracat ile alt bileşenleri (aramalları ve sermaye malları) ve toplam ithalat ile alt bileşenleri (aramalları ve sermaye malları) arasındaki nedensel ilişkilerinin araştırılması amaçlanmaktadır. Çalışmada değişkenler arasındaki nedensellik ilişkileri Hacker ve Hatemi- J Bootstrap Toda-Yamamoto ve Zamanla Değişen Nedensellik testleri kullanılarak araştırılmıştır. Analiz sonuçları, uluslararası turizm talebi ile ihracat ve ithalat arasında nedensellik ilişkilerin istikrarsız olduğunu göstermektedir. Başka bir ifadeyle zamanla değişen bir yapıya sahiptir. Ayrıca, uluslararası turizm talebinin ithalata katkısı, ihracata katkısından daha büyüktür. Son olarak, uluslararası turizm talebinin ihracat ve ithalat bileşenlerine etkisi genellikle pozitif yöndedir. $\mathrm{Bu}$ nedenle politika yapıcıları, sektör temsilcileri ve piyasa profesyonelleri hem uluslararası ticareti hem de uluslararası turizmi teşvik etmeyi amaçlayan politikaları geliştirmeden ve uygulamadan önce değişkenler arasında tespit edilen zamanla değişen nedensellik ilişkilerini göz önüne almalıdırlar.

Anahtar Kelimeler: Uluslararası Turizm Talebi, Uluslararası Ticaret, Hacker ve Hatemi-J Bootstrap TodaYamamoto Testi, Zamanla Değişen Nedensellik Testi

Jel Sinıflnadırımlası: C22, F14, Z32

\footnotetext{
${ }^{1}$ This article is derived from the $\mathrm{PhD}$ thesis which is written under the supervision of Prof. Dr. Mustafa ÖZER by Mustafa KIRCA in Anadolu University, Eskişehir, Turkey. Title of the Thesis: "The Econometric Analysis of the Relationships Between Selected Macroeconomic Variables and Tourism in Turkey". This thesis was supported by Anadolu University Scientific Research Projects (BAP). (Project No: 1506E488)

$2 \mathrm{PhD}$, Assistant Professor, Düzce University, Akçakoca Bey Faculty of Political Sciences, Department of Economics, mustafakirca52@gmail.com, Orcid: 0000-0002- 5630-7525

${ }^{3} \mathrm{PhD}$, Professor, Anadolu University, Faculty of Economics Administrative Sciences, Department of Economics, muozer@ anadolu.edu.tr, Orcid: 0000-0001-9852-8441
}

Makale Türü: Araştırma Makalesi - Geliş Tarih:17/01/2020 - Kabul Tarihi:27/03/2020

DOI:10.17755/esosder.676462

Atıf için: Elektronik Sosyal Bilimler Dergisi, 2020; 19(75):1212-1231 


\section{INTRODUCTION}

Following the adoption of market-based policies in 1980's, Turkey's economy has become more export oriented and gradually the services sectors dominated economy (Özer, 2015). Domination of services sectors mostly resulted from rise of the portion of tourism sector and tourism related services sectors such as hotels and resorts, travel agencies, restaurants, and souvenir shops. As the Turkey's economy has started operating in a small-open macroeconomic condition, the tourism has become one of the key economic activities in Turkey. Since then, international tourism sector has experienced continued expansion, becoming one of the largest and fastest-growing economic sectors in Turkey (Gül \& Özer, 2018)

International tourism has contributed to growth of Turkey, by allowing to pay imported capital goods and basic inputs, especially for manufacturing sector, with the foreign exchange earnings of sector. At the same time, these foreign exchange earnings have been used to improve the balance of payments of Turkey. Moreover, as a leading service sector, international tourism has provided the several benefits for related businesses, such as hotels and resorts, travel agencies, restaurants, and souvenir shops. These businesses also contributed to the development of Turkey by attracting foreign money and generating income which is then distributed and used throughout the country. Because of the backward and forward linkages of tourism sector in Turkey, the sector also has contributed to the development of energy, telecommunications and environmental services; agriculture, manufacturing and other support services. The sector's contribution to the development of the tourists need supplying services of the financial, telecommunications, retail, recreational, cultural, personal, hospitality, security and health services are significant and extraordinary. As a result, Turkey has become the leading country in providing the exports of health services. By creating income, taxes, hard currency and jobs out of these activities, international tourism has helped the country to overcome the problems of unemployment, inflation and stagnant and erratic growth.

Apart from international tourism, since early 1980s in Turkey, the importance of international trade (imports and exports) is well recognized to have sustained and healthy economic growth. Besides its direct connections with the sectors of agriculture and industry, there are strong links between international trade and the service sector, including international tourism. Especially in recent decades, the tourism exports have been one of the major drivers of economic growth in many emerging and developing countries, like Turkey. Thus, international tourism should be seen as an important impetus to promoting export trade and economic growth in Turkey.

Even though there is close connection between international trade and international tourism and how important these sectors together to have sustained and balanced economic growth, there is lack of empirical studies investigating the relations between two. Thus, our contribution to literature has twofold. First of all, to the best of our knowledge, this is the first attempt to investigate relationship between international tourism demand and international trade by focusing on not only total exports and imports but also, the intermediate and capital goods export and import in Turkey. Secondly, this is also first attempt to analyze the key relationship by using time-varying causality method. By using this method, we try to establish that the relationship depends on time. In traditional Granger causality analysis, one can have only a chance of providing one shot of whole sample. But, during the sample period, the established causal relationship can be subject to change by either changing direction or changing sign or breaking 
down. Thus, this method allows us also to determine overcome of these drawbacks of traditional methods.

In this study, we investigate the causal relationships between Turkish international tourism and total exports, total imports, and intermediate and capital goods exports and imports goods using time-varying causality method, while being aware of the positive effects of tourism, such as balance of payments support through the creation of foreign exchange inflows, job creation and support for foreign trade, infrastructure and superstructure. For this purpose, we first explain the relationship between international trade and international tourism and continue to present the literature review and introducing methodology and data used in empirical analysis. Finally, we discuss the empirical results and conclude.

\section{THE INTERNATIONAL TRADE AND INTERNATIONAL TOURISM: THEORETICAL AND EMPIRICAL LITERATURE}

Unlike the importance of international trade and international tourism in the development of countries, unfortunately, economic theory does not provide too much insights on the relationship between international trade and international tourism. As we mentioned in the introduction, international trade is also linked to the service sector, including international tourism. According to several studies carried out, such as Chaisumpunsakul \& Pholphirul (2018) and Turner \& Witt (2001), it generally appears that countries which increase their international trade are becoming more open and at the same time, travel is increasing in these countries. It is an important source of export earnings for any country but little mention is made of tourism. Tourism can be considered as a form of temporary international migration. Indeed, repeated visits and the pleasure of friends and relatives of visits entail obtaining information on the country of destination; which could favor a future business visit.

The first scientific efforts towards explaining the dynamics of international trade begins with Adam Smith's acclaimed work "Wealth of Nations" published in 1776. Besides Adam Smith, works of David Ricardo also has important contributions to explain the advantages of international trade. the "Absolute advantages Theory" developed by Adam Smith and the "Comparative advantages Theory" developed by David Ricardo are the fundamental theories explaining the gains from trade.

According to Socher (1986), tourism was not explicitly included in the international trade theories, because first theories on international trade developed in back in the 18th and 19th centuries and tourism activities being virtually non-existent in those centuries. Likewise, as Seyidoğlu (2007) expressed, the primary goal of international trade theory was to explain the reasons why nations engage international trade of goods, and emphasized that the research on international service trade has not been limited.

As Socher (1986) indicated, Peter Gray is the first researcher emphasizing the potential relations between international tourism and international trade. The subject was elaborated in the book written by Gray in the year 1970 with the title of International Trade - International Travel. According to Santana-Gallego et al. (2011:533), the first studies on the subject was related to OECD countries, investigating the effects of rising international trade on international travel.

As is well known, there are many reasons of international travel of individuals such as pleasure, adventure, curiosity, business, friend and relative visits, education, sports and recreation. World Tourism Organisation (UNWTO) (2014) published that $14 \%$ of all 
international tourists travelled for business and professional reasons in 2013. This ratio explains the importance of business and professional purposed travels within overall international travel.

To explain the relations between international trade and international travel, Kulendran \& Wilson (2000:1002) classified international travel as business trips, holiday travels, friend and relative visits and other travels. Kulendran \& Wilson, (2000:1002) has begun their research on the relations between international trade and international travel by examining the impacts to be generated due to business trips. According to Kulendran \& Wilson (2000:1002), those who travel with business purposes go to a country either for purchasing the goods in that country or for selling a certain product to that country. Thus, export and import flows arise due to business trips. The agreements that are made during such travels also cause to increase of trade relations to occur in the future. Likewise, Khan, Toh, \& Chua (2005:171) have claimed that there are significant relations between business-purpose travel and international trade. According to Khan, Toh, \& Chua (2005:171), tourists who travel with business purposes may conduct sale agreements or may visit countries with the purpose of goods or service purchases or establishing partnerships. In addition to them, government representatives can also make business trips with a purpose of creating bilateral or multilateral trade agreements. Thus, business travel may have impacts in increasing international trade.

Kulendran \& Wilson (2000) indicated that such business travel may have a series of external impacts. According to Kulendran and Wilson (2000:1002), the businessman will always seek better business opportunities in other countries. Also, increase in business travels may lead to the increase in holiday travels, friend and relative visits, and travels with adventure or pleasure purposes. They may also occur together, at the same time with the business travels. Furthermore, rising imports from certain countries may cause an increase in travel to exporter countries, because of the consumers' increase interest in these countries. Such interest and awareness may lead, in the future, to holiday-purposed travels. In sum, business travels will create and exports and imports of goods and services followed by further business and holiday trips as well.

Again, Kulendran \& Wilson (2000:1002), indicated that other types of travel may have greater impact on international trade compared to the impacts to be generated through business travel. As a matter of fact, according to Khan, Toh, \& Chua (2005:171), tourists travelling for different purposes directly consume goods and services. For instance, foreign tourists visiting a country buy services such as accommodation and transportation from that country. Also, they purchase goods that are subject to import such as souvenirs, food and gas. According also to Vellas \& Bécherel (1995:242), holiday travels may increase import. Kulendran \& Wilson (2000:1002) similarly indicated that, through development of tourism industry at destinations with tourism value would increase the import aimed at that destination, and emphasized that this would affect the trade balance. Santana-Gallego et al. (2011:534) mentioned that there are potential complementarity connections between good flows and international tourism. On the other hand, Kulendran \& Wilson (2000:1002) indicated that there is a causality running from international trade to international tourism and explained source of this causality as follow: "In the event import goods display an effect towards increasing the satisfaction of a country's citizens, this situation creates a positive effect on the citizens' will towards visiting the country that sends such goods."

According to Khan, Phang, \& Toh (1995), "when a foreign visitor orders Beefeater Gin (this is a product imported from England) at the famous Raffles Hotel in Singapore, he might order Cherry Heering (this is a product imported from Denmark) and pineapple (this is a product 
imported from Malaysia). In fact, 36 cents of each dollar spent by a tourist in Singapore is transferred to foreign goods and services."

The immigrants can promote tourism in their host country with family and friends ( Oigenblick \& Kirschenbaum (2002)) as immigrants carry their preferences of goods and services with them from the country of origin.

Table 1 summarizes the empirical literature about the relationships between international trade and international tourism demand.

Table 1. Literate Review

\begin{tabular}{|c|c|c|c|c|}
\hline Author(s) & Countries & Period & Method & Results \\
\hline Egeli (1997) & Turkey & 1990 & $\begin{array}{l}\text { input-output analysis- } \\
\text { regression analysis }\end{array}$ & $\begin{array}{l}\text { He concludes that the share of } \\
\text { tourism sector imports and export } \\
\text { within production had declined to } \\
\text { some degree, while the contribution } \\
\text { of tourism to the country's foreign } \\
\text { exchange earnings had been high, and } \\
\text { import dependency of sector had been } \\
\text { arguably low. }\end{array}$ \\
\hline $\begin{array}{l}\text { Bahar \& } \\
\text { Baldemir (2008) }\end{array}$ & Turkey & $1980-2005$ & Granger causality tests & $\begin{array}{l}\text { There is a unidirectional causality } \\
\text { from tourism to export }\end{array}$ \\
\hline Polat et al. (2010) & Turkey & 1997:1-2010:1 & $\begin{array}{c}\text { Johansen cointegration and } \\
\text { causality analyses }\end{array}$ & $\begin{array}{l}\text { They found short-run causality among } \\
\text { the variables, but not long-run } \\
\text { causality. }\end{array}$ \\
\hline $\begin{array}{l}\text { Kulendran \& } \\
\text { Wilson (2000) }\end{array}$ & $\begin{array}{l}\text { Australia and her four trading } \\
\text { partners of USA, England, } \\
\text { New Zealand and Japan }\end{array}$ & 1982:1-1997:4 & $\begin{array}{c}\text { Cointegration and Granger } \\
\text { Causality tests }\end{array}$ & $\begin{array}{l}\text { They find the evidences of causal } \\
\text { relations between international } \\
\text { tourism and international trade. }\end{array}$ \\
\hline $\begin{array}{l}\text { Shan \& Wilson, } \\
\text { (2001) }\end{array}$ & China & 1987:1-1998:1 & $\begin{array}{l}\text { Toda and Yamamoto } \\
\text { Causality tests }\end{array}$ & $\begin{array}{l}\text { There was a bidirectional causality } 6 \\
\text { between China's international trade } \\
\text { and tourism. }\end{array}$ \\
\hline $\begin{array}{l}\text { Tang, } \\
\text { Selvanathan, \& } \\
\text { Selvanathan } \\
(2007)\end{array}$ & China & 1985:1-2001:3 & Granger causality & $\begin{array}{l}\text { There is a unidirectional causality } \\
\text { from foreign direct investments to } \\
\text { tourism. }\end{array}$ \\
\hline $\begin{array}{l}\text { Khan \& Lin } \\
(2002)\end{array}$ & Singapore & $1978-2000$ & $\begin{array}{l}\text { Cointegration analysis and } \\
\text { Granger causality tests }\end{array}$ & $\begin{array}{l}\text { They found evidences of long-term } \\
\text { relations between tourism and trade } \\
\text { and Granger causality between certain } \\
\text { variables for many countries. }\end{array}$ \\
\hline $\begin{array}{l}\text { Khan et al. } \\
(2005)\end{array}$ & Singapore & $1978-2000$ & $\begin{array}{l}\text { Cointegration analysis and } \\
\text { Granger causality tests }\end{array}$ & $\begin{array}{l}\text { They found strong connections } \\
\text { between business-purpose travels and } \\
\text { import. }\end{array}$ \\
\hline $\begin{array}{l}\text { Kg, Gautam, \& } \\
\text { Kumar (2011) }\end{array}$ & India & 1996-2009 & Cointegration tests & $\begin{array}{l}\text { There was a long-term relation among } \\
\text { tourism, foreign trade and economic } \\
\text { growth. However, they failed to } \\
\text { indicate the existence of short-term } \\
\text { relations among the variables }\end{array}$ \\
\hline $\begin{array}{l}\text { Gautam, V. \& } \\
\mathrm{Kg},(2012)\end{array}$ & $\begin{array}{l}\text { The bilateral trade and } \\
\text { tourism of India with } \\
\text { Germany, Netherlands, } \\
\text { Switzerland, France, Italy, } \\
\text { USA, England and Canada }\end{array}$ & $\begin{array}{l}\text { 1996:1- } \\
2008: 12\end{array}$ & Granger causality & $\begin{array}{l}\text { There was a bidirectional causality } \\
\text { between these two variables for USA, } \\
\text { Italy and Canada. }\end{array}$ \\
\hline $\begin{array}{l}\text { Kadir \& Jusoff } \\
(2010)\end{array}$ & Malaysia & 1995:1-2006:4 & $\begin{array}{l}\text { Cointegration analysis and } \\
\text { Granger causality tests }\end{array}$ & $\begin{array}{l}\text {-No long-term connections among the } \\
\text { variables. } \\
\text {-Unidirectional causality from export } \\
\text { to international tourism incomes. } \\
\text { - Unidirectional causality from import } \\
\text { to international tourism incomes. -- } \\
\text { Unidirectional causality from overall } \\
\text { foreign trade to international tourism }\end{array}$ \\
\hline
\end{tabular}


incomes.

These findings led the authors to conclude that the tourism in Malaysia is related heavily to business tourism.

Sarmidi \& Mohd

Salleh (2011)
Malaysia 1997:1-2007:4

Malaysia

$1997-2008$

OLS

Jamaluddin

(2011)

\section{Suleiman \&}

Albiman (2014)
Malaysia

$1999-2010$

According to the conclusion of study, the impact of the development of tourism was not limited to itself but also interrelated with both international trade and economic growth.

There was a strong connection between tourism demand and international trade.

They conclude that only foreign trade positively affected economic growth in the long-run and there was causality among also tourism, infrastructure investments and economic growth in addition to foreign trade in the short term.

They found some evidences of bidirectional causal relations between

Majewska \&

Minska-Struzik (2012)

Poland

1993-2010 and

2005-2010

$987 \mathrm{q} 1$

$2009 q 4$

Mattana (2013)

Italy

$2006-2010$

\begin{tabular}{l}
\hline Brahmbhatt \& \\
Menezes (2013) \\
\hline
\end{tabular}

World

2006-2010

1998:1-

Fischer \& Gil-

Alana (2009)

Spain/Germany

2004:11

theression models run causality international tourism movements and international trade.

There were causality running from real GDP to international trade and from international trade $12 \varphi 7$ international tourism demand. There was strong relation between tourism and trade.

They found some evidences that tourism was effective on wine import especially during the 2nd and 9th months of the year and concluded that tourism contributes to local development.

They conclude that the foreign tourists visiting countries may encourage international trade. In addition, they indicated that the

Santana-Gallego et al. (2011)

OECD

1980-2006

Panel Data Methods
Chaisumpunsakul \& Pholphirul (2018)
Thailand

$1998-2010$

Santana-Gallego, et al. (2016)

195 countries

2012

Gravity model /Dynamic Panel Data Estimator international flow of goods also may increase the numbers of foreign tourists visiting countries. Furthermore, they stated the existence of short-term relations between tourism and trade.

Tourism increases both the possibility of two countries engaging trade and the volume of international trade between them.

They find that there is a positive correlation between the degree of trade openness and international tourism demand and conclude that the empirical evidences of study do support Thailand's recent policies for promoting international trade and international tourism. 
The related literature review shows that even though there are a number of studies aiming to examine the relationship between international trade and international tourism, there is an obvious need of studying the same relations by using econometric techniques taking into account of time varying nature of causal relations between two variables. Time varying nature of the causal relations might have the capacity provide results for designing an efficient foreign trade policy along with tourism policies. Moreover, the study should document the implied relations between two variables by focusing on the intermediate and capital goods exports and imports.

\section{METHODOLOGY AND DATA}

In this section, we explain the methods and data used to investigate the causal relations between international tourism demand and total exports and imports and the intermediate and capital goods exports and import. To carry out empirical analysis, we first determine the degree of the integration of each variable by using traditional unit root tests of Augmented DickeyFuller (ADF), Phillips-Perron (PP), and Kwiatkowski-Phillips-Schmidt-Shin (KPSS). After determining the degree of the integration of the variables, we carry out, Hacker \& Hatemi-J Bootstrap Toda-Yamamoto and time-varying causality tests to explore the direction and sign of the causal relations among the variables.

According to Hacker \& Hatemi-J (2006), the residual terms obtained in the causality test developed by Toda \& Yamamoto (1995) may be subject to deviations from normal distribution, since the more abundant presence of volatilities in the formation process especially of long time series trigger the deviation of error terms from the normal distribution. Taking this point into consideration, Hacker \& Hatemi-J (2006) developed the Bootstrap Toda-Yamamoto causality test. They indicate that this problem would be eliminated through the use of Bootstrap method.

Hacker \& Hatemi-J (2006:1490), tested the existence of causality between variables by using a model of $\operatorname{VAR}\left(\mathrm{p}+\mathrm{d}_{\max }\right)$ as in the Toda-Yamamoto (1995) causality test, and expressed the model as follow;

$$
y_{t}=\hat{v}+\hat{A}_{1} y_{t-1}+\cdots+\hat{A}_{p} y_{t-p}+\cdots+\hat{A}_{p+d} y_{t-p-d}+\hat{\varepsilon}_{t}
$$

Where $\mathrm{y}_{\mathrm{t}}$ indicates a variable vector with a dimension of $(2 \times 1)$, while $\hat{A}$ represents the vector of coefficients. The model can be rewritten as follow;

$$
Y=\widehat{D} Z+\hat{\delta}
$$

Where $\mathrm{Y}$ is a matrix with $(\mathrm{n} \mathrm{x} \mathrm{T})$ dimension and $\mathrm{Y}=\left(\mathrm{y}_{1}, \ldots \mathrm{y}_{\mathrm{T}}, \mathrm{T}\right.$ is the number of observations); $\widehat{D}$ indicates a matrix with $(\mathrm{n} \times(1+\mathrm{n}(\mathrm{p}+\mathrm{d})))$ dimension in the form of $\widehat{D}:=$ $\left(\hat{v}, \hat{A}_{1}, \ldots, \hat{A}_{p}, \ldots, \hat{A}_{p+d}\right)$,

$$
\begin{aligned}
& Z_{t}:=\left[\begin{array}{c}
1 \\
y_{t} \\
y_{t-1} \\
\cdot \\
\cdot \\
\cdot \\
y_{t-p-d+1}
\end{array}\right] ; \text { a matrix with }((1+\mathrm{n}(\mathrm{p}+\mathrm{d})) \times 1) \text { dimension, } \\
& Z:=\left(\mathrm{Z}_{0}, \ldots, \mathrm{Z}_{\mathrm{T}-1)} ; \text { a matrix with }((1+\mathrm{n}(\mathrm{p}+\mathrm{d})) \times \mathrm{T})\right. \text { dimension, }
\end{aligned}
$$


$\hat{\delta}:=\left(\hat{\varepsilon}_{1}, \ldots, \hat{\varepsilon}_{T}\right) ;$ a matrix with $(\mathrm{n} \times \mathrm{T})$ dimension.

Hacker and Hatemi-J (2006) derived a new modified Wald statistics (MWALD) by using the model in Equation (4). MWALD statistics is calculated as below;

$$
M W A L D=(C \hat{\beta})^{\prime}\left[C\left(\left(Z^{\prime} Z\right)^{-1} \oplus S_{U}\right) C^{\prime}\right]^{-1}(C \hat{\beta})
$$

Where $\mathrm{C}$ is the indicator function that includes the limits, and is a matrix with dimension equal to $\mathrm{p} \times \mathrm{n}(1+\mathrm{n}(\mathrm{p}+\mathrm{d}))$. $\oplus$ is the Kronecker multiplier. $\beta$ is expressed as $\beta=\operatorname{vec}(\widehat{D})$ and indicates the vec column deposition operator. $S_{u}$ indicates the variance-covariance matrix calculated for the limitless VAR model, and is calculated as $s_{u}=\delta_{U}^{\prime} \delta_{U} / T$. MWALD statistics has the asymptotic distribution of $\chi^{2}(p)$.

Following hypotheses are tested:

$\mathrm{H}_{0}$ : $\mathrm{C} \beta=0$ (There is no Granger causality between variables),

$\mathrm{H}_{1}: \mathrm{C} \beta \neq 0$ (There is Granger causality between variables).

When the computed value of MWALD statistics is greater than the critical value produced by the bootstrap method, $\mathrm{H}_{0}$ is rejected. This result is taken as evidence of Granger causality between the variables.

The causality tests we explain so far are testing the presence of causality over entire sample period. So they provide one sample results for whole period. But, according to Arslanturk, Balcilar, \& Ozdemir (2011), because of the structural changes over the sample period, there is no guarantee that the established causal relations will hold. That is, the causal relations between variables could have a time-varying nature.

To take into account of this time-varying nature of causality, Balcilar, Ozdemir, \& Arslanturk (2010) developed a test based on Toda \& Yamamoto (1995) causality test. They implement a rolling window causality analysis. In their method, to analyze the effect of structural change, they use the rolling-window Granger-causality tests, based on the modified bootstrap test. If there is a structural change in the coefficients of VAR model, one can find instability across different sub-samples of the dynamic linkages between variables in question. To take into account of this instability, following Balcilar et al. (2010), we apply the bootstrap causality test to rolling-window sub-samples for $\mathrm{t}=\tau-l+1, \tau-l, \ldots, \tau, \tau=l, l+1, \ldots, \mathrm{T}$, where $l$ is the size of the rolling window.

As is explained fully in Balcilar and Ozdemir (2013), implementing the rolling-window method, a researcher uses a fixed-length moving window sequentially from the beginning to the end of the sample by adding one observation from ahead and dropping one from behind. Notice in this process that each rolling-window sub-sample includes $l$ observations. In each step of the process, the causality test is applied to each sub-sample, providing a $(\mathrm{T}-l)$ sequence of causality tests, as opposed to just one because of the two main reasons (Nyakabawo, Miller, Balcilar, Das, \& Gupta, 2015): First, the rolling window approaches recognize the fact that the relationship between variables changes over time. And, secondly, there will be an instability across different sub-samples caused by structural change and the rolling-window estimation take into account this process.

In this method, the LR statistics modified for each rolling window is calculated for each subperiod. This statistic has a $\chi^{2}$ distribution and is calculated as follows: 


$$
L R=(T-k) \ln \left(\frac{\operatorname{det} S_{R}}{\operatorname{det} S_{U}}\right)
$$

Where $\mathrm{T}$ is total number of observations, $k=2 \times(2 p+1)+p$, det $\mathrm{S}_{\mathrm{U}}$ covariant matrix of the unrestricted model, det $\mathrm{S}_{\mathrm{R}}$ covariant matrix of the restricted model. $\mathrm{S}_{\mathrm{u}}=\delta_{\mathrm{u}}^{\prime} \delta_{\mathrm{u}}$ and $S_{r}=\delta_{r}^{\prime} \delta_{r}$. Periods where the probability values of the LR statistics are lower than 0.20 are periods of causality between variables. After determining the periods that the causality exists, we compute the causality coefficients at 5\% significance level for each period, and identify the sign of the causality.

In the study, we use Intermediate goods export (LNARAMALIH), Capital goods export (LNSMIH), Total Export (LNTIH), Intermediate goods import (LNARAMALIT), Capital goods import (LNSMIT), Total Import (LNTIT) and International tourism demand (Number of Foreign Visitors, LNYZ) ${ }^{4}$. Because of the frequent changes made in calculations of and inconsistencies of data, we did not extend de sample period beyond 2013.

\section{EMPIRICAL RESULTS}

To examine the causal relationships between tourism demand, import and export variables, we first determined the degree of integration of variables by using traditional unit root tests of Augmented Dickey-Fuller (ADF), Phillips-Perron (PP) and Kwiatkowski-Phillips-Schmidt-Shin (KPSS) unit root tests. The results of the unit root tests indicate that all variables are integrated of order one, i.e. I(1) ${ }^{5}$. Thus, we continue carrying out, Bootstrap Toda-Yamamoto and TimeVarying Causality tests.

\subsection{Bootstrap Toda-Yamamoto Causality Test Results}

Hacker and Hatemi-j (2006) Bootstrap Toda-Yamamoto causality test results are presented in Table 2.

Table 2. Bootsrap Toda-Yamamoto causality test results.

\begin{tabular}{|c|c|c|c|c|c|}
\hline Hypotheses & $\operatorname{Lag}\left(p+d_{\max }\right)$ & MWald-Statistics & $1 \%$ & $5 \%$ & $10 \%$ \\
\hline LNYZ is not Granger cause of LNARAMALIH. & 3 & 0.159 & 9.587 & 6.191 & 4.686 \\
\hline LNYZ is not Granger cause of LNARAMALIT. & 2 & 0.022 & 6.595 & 3.817 & 2.638 \\
\hline LNYZ is not Granger cause of LNSMIH. & 4 & 2.077 & 11.967 & 8.116 & 6.353 \\
\hline LNYZ is not Granger cause of LNSMIT. & 3 & 2.27 & 9.454 & 5.827 & 4.557 \\
\hline LNYZ is not Granger cause of LNTIH. & 3 & 0.141 & 10.272 & 6.221 & 4.774 \\
\hline LNYZ is not Granger cause of LNTIT. & 3 & $9.323 *$ & 9.213 & 5.964 & 4.605 \\
\hline LNARAMALIH is not Granger cause of LNYZ. & 3 & 3.022 & 9.447 & 6.001 & 4.592 \\
\hline LNARAMALIT is not Granger cause of LNYZ. & 2 & 1.079 & 6.68 & 3.967 & 2.77 \\
\hline LNSMIH is not Granger cause of LNYZ. & 4 & $11.254 * *$ & 11.986 & 8.174 & 6.545 \\
\hline LNSMIT is not Granger cause of LNYZ. & 3 & $5.734 * * *$ & 9.552 & 6.167 & 4.686 \\
\hline LNTIH is not Granger cause of LNYZ. & 3 & $8.006^{* *}$ & 9.892 & 6.128 & 4.707 \\
\hline
\end{tabular}

${ }^{4}$ Imports and exports data were extracted from the Central Bank of the Republic of Turkey (TCMB) Electronic Data Delivery System (EVDS). Data on the number of foreign visitors taken as an indicator of international tourism demand were obtained from the Turkish Statistics Institute (TURKSTAT). The data consists of monthly observations over period of 1990 and 2013.

${ }^{5}$ To save the space, we did not include the results of unit root tests. They are avaliable upon request. 
LNTIT is not Granger cause of LNYZ.

3

$11.414^{*}$

9.61

$6.142 \quad 4.703$

$*, * *, * * *$ indicate statistical significance of $1 \%, 5 \%$ and $10 \%$, respectively.

Lags were determined by HJC criteria.

According to the test results in Table 2, LNYZ variable Granger causes LNTIT variable at $1 \%$ significance level. But, it does not Granger cause any other international trade variable. On other hand, LNSMIH, LNSMIT, LNTIH and LNTIT variables Granger cause LNYZ variable at different level of significance. Both the Standard Toda-Yamamoto and the Bootstrap TodaYamamoto Causality tests results indicate a causal relationship between LNYZ and LNTIT. Also, they concluded that LNSMIH, LNSMIT, LNTIH and LNTIT variables Granger cause LNYZ variable.

\subsection{Time-Varying Causality Tests Results}

All the tests carried out so far use the entire sample period. But, the direction and sign of causality and even existence of causality are all subject to change during the sample period, Whereas, the directions of the determined causalities have taken the case into account an approach, so-called rolling window approach producing time-varying causalities developed by Balcilar et al. (2010). In this section, we present and discuss the results of time-varying causality test results. To do this, we first interpret the results of the LR test results and then examine the sign of the causality and the significance of estimated coefficients.

Figure 1 presents the results of test statistics and coefficient estimates for time-varying causality between LNARAMALIH and LNYZ variables.
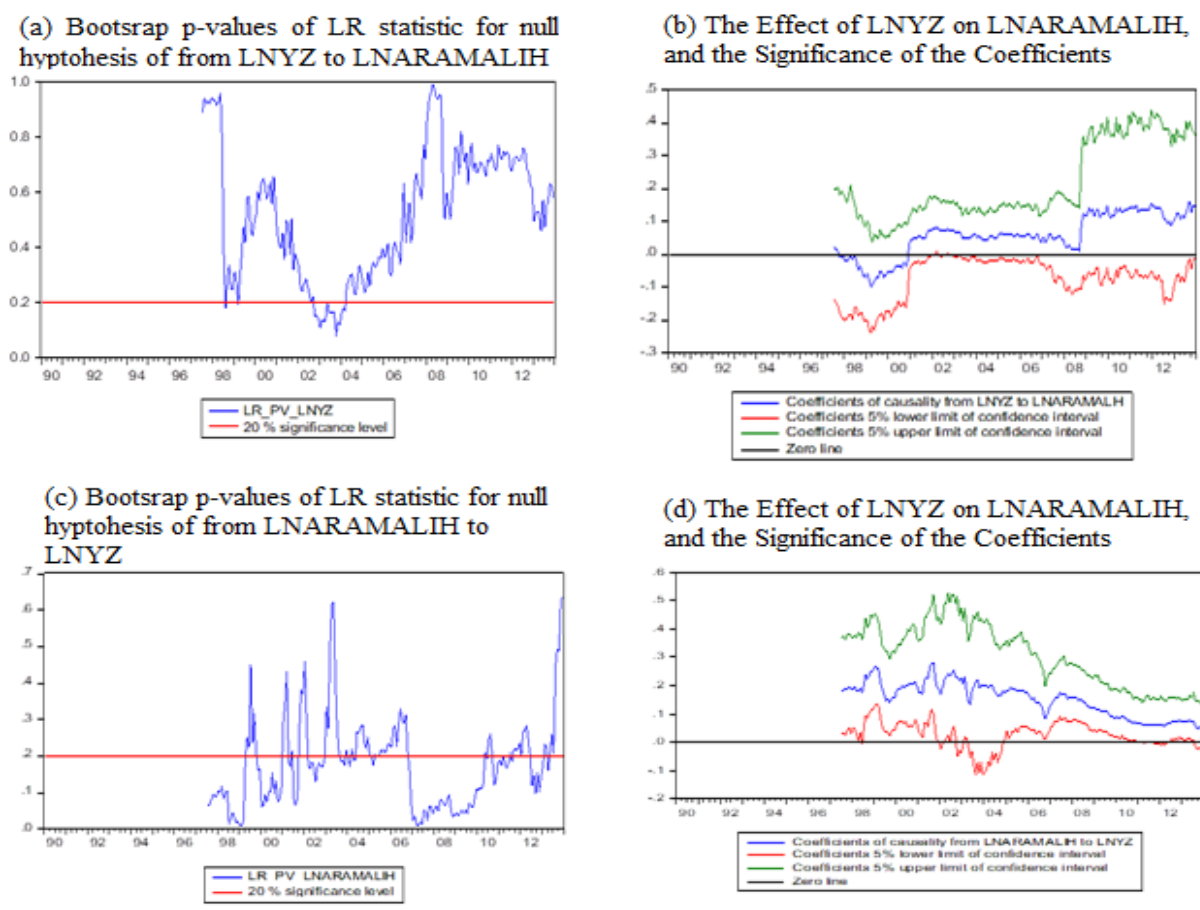

(d) The Effect of LNYZ on LNARAMALIH, and the Significance of the Coefficients

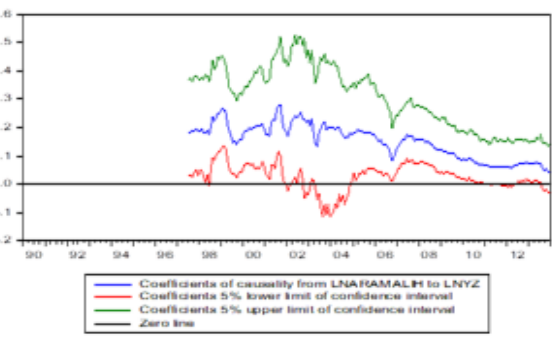

Figure 1. Rolling Window Estimates of Relationships Between LNYZ and LNARAMALIH

The p-values of LR statistic in Figure 1, Panel (a) indicates the presence of causality from LNYZ to LNARAMALIH in periods of 1999M03, 2002M08, and between 2002M10 and 2004M03. Also, Figure 1, Panel (b) shows that the estimated coefficients are the significant at $5 \%$ significance level, and LNYZ have positive effect on LNARAMALIH during all causality 
periods except for 1999M03 period. The p-values of LR statistic in Figure 1, Panel (c) provides evidences of the time-varying causality from LNARAMALIH to LNYZ in periods of between 1994M07 and 1999M04, between 1999M11 and 2000M12, between 2001M04 and 2001M05, between 2001M07 and 2001M09, between 2002M03 and 2002M12, between 2003M09 and 2003M11, between 2004M01 and 2004M02, between 2004M04 and 2004M05, between 2005M02 and 2005M03, 2005M05 period, between 2006M11 and 2010M04, 2010M06 period, between 2010M09 and 2011M06, 2011M08, between 2012M07 and 2013M01, and 2013M04. Figure 2, Panel (d) shows that the estimated coefficients are all significant at 5\% significance level, and they have positive effect during all of the causality periods.

Figure 2 shows the results of time-varying causality between LNYZ and LNARAMALIT.

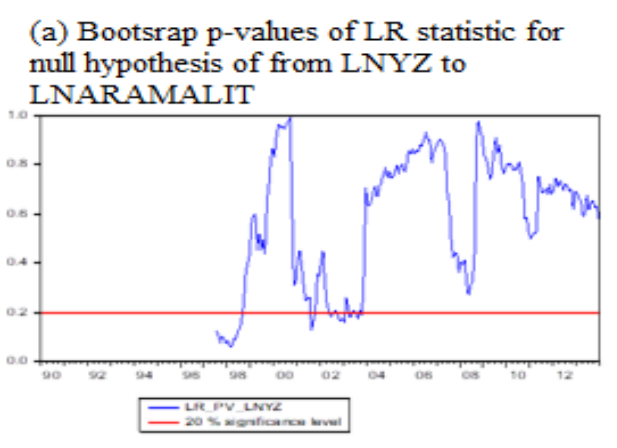

(b) The Effect of LNYZ on

LNARAMALIT, and the Significance of the Coefficients

(c) Bootsrap p-values of LR statistic for null hypothesis of from LNARAMALIT to LNYZ
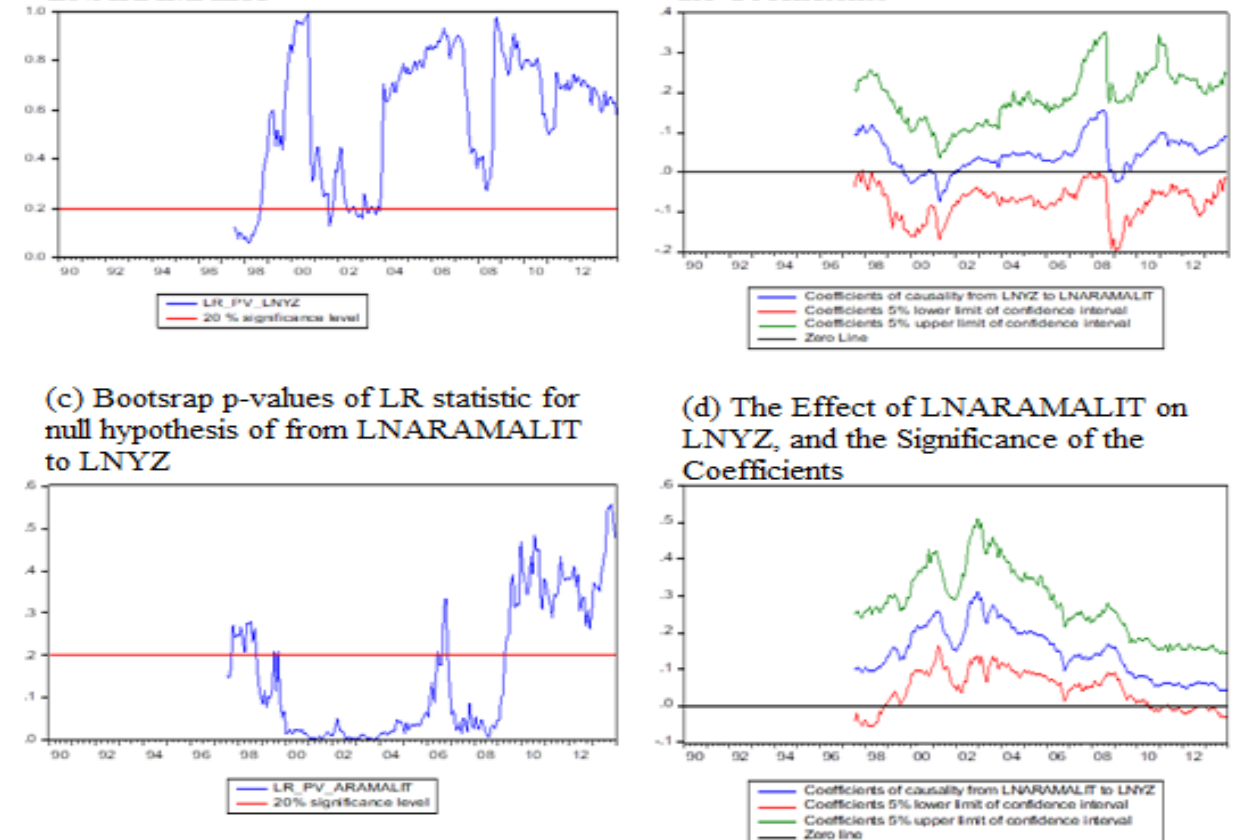

(d) The Effect of LNARAMALIT on

LNYZ, and the Significance of the Coefficients

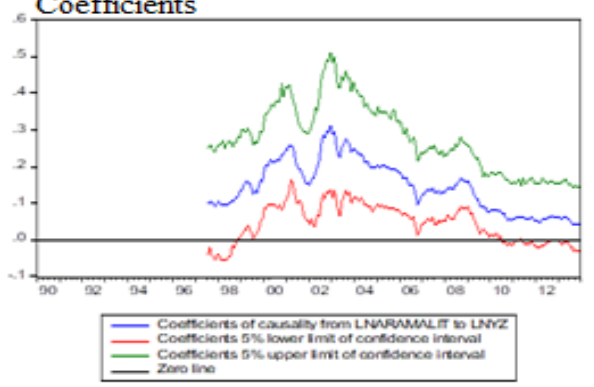

Figure 2. Rolling Window Estimates of Relationships Between LNYZ and LNARAMALIT

When p-values in Figure 2, Panel (a) indicate presence of causality from LNYZ to LNARAMALIT during the following periods: between 1999M07 and 1998M08 periods, between 2001M08 and 2001M09 periods, between 2005M05 and 2002M07 periods, between 2002M10 and 2003M01 periods, 2003M04 period, between 2003M07 and 2003M08 periods, and 2003M10 period. The results regarding the significance of coefficients in Figure 2, Panel (b) illustrates that they are significant and LNYZ has a positive effect on LNARAMALIT during all causality periods except for 2001M08-2001M09 period. Figure 2, Panel (c) depicts the timevarying causality results from LNARAMALIT to LNYZ. According to these results, the following periods are the periods that there exists a causality from LNARAMALIT to LNYZ: between 1997M07 and 1997M09, between 1998M10 and 199M06, 1998M08, between 1999M10 and 2006M05, between 2006M07 and 2006M08, between 2006M12 and 2009M03. The results in Figure 2, Panel (d) shows that the estimated coefficients are significant and have a positive sign. 
Figure 3 depicts the result of time-varying Granger causality tests between LNYZ and LNSMIH.

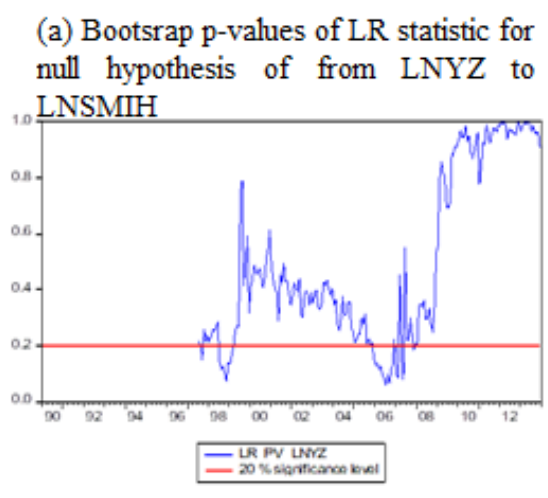

(c) Bootsrap p-values of LR statistic for null hypothesis of from LNSMIH to LNYZ

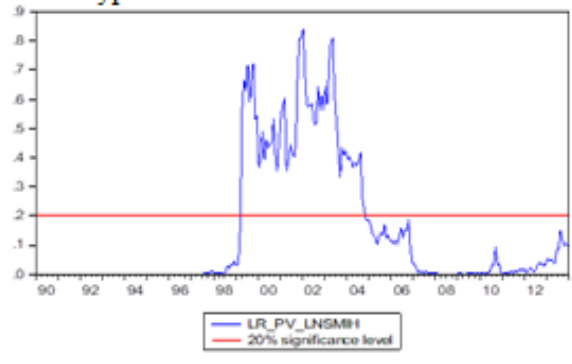

(b) The Effect of LNYZ on LNSMIH, and the Significance of the Coefficients

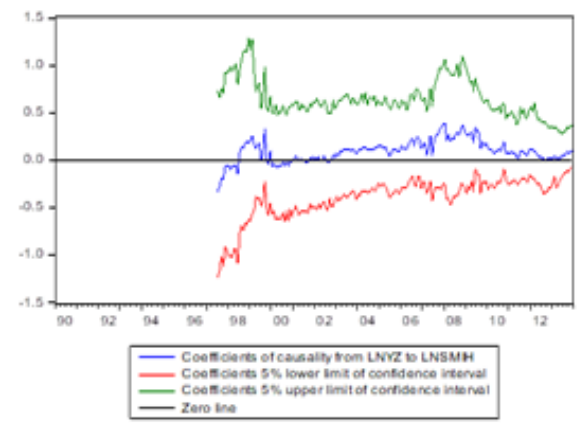

(d)The Effect of LNSMIH on LNYZ,

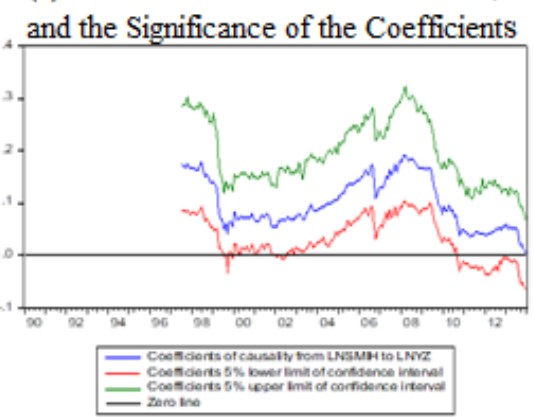

Figure 3. Rolling Window Estimates of Relationships Between LNYZ and LNSMIH

The p-values of test statistic in Figure 3, Panel (a) provides evidences of presence of causality from LNYZ to LNSMIH for the following periods: between 1997M08 and 1997M09, between 1998M07 and 1999M02, between 2005M12 and 2006M11, between 2007M01 and 2007M02, between 2007M04 and 2007M05, 2007M11, and 2008M01 period. Also, Figure 3, Panel (b) illustrates that the estimated coefficients are statistically significant at 5\% significance level and LNYZ have positive effect on LNSMIH variable during all causality periods except for the 1997M08-1997M09 period. Figure 3, Panel (c) depicts the results of time-varying causality results from LNSMIH to LNYZ and the results show there is causality from LNSMIH towards LNYZ in following periods: between 1997M07 and 1999M03, between 2004M11 and 2013M12.Also, the results presented in Figure 3, Panel (d) show that all estimated coefficients are significant and they indicated positive causality during all periods.

In Figure 4, we present the results of time-varying causality results between LNSMIT and LNYZ. 


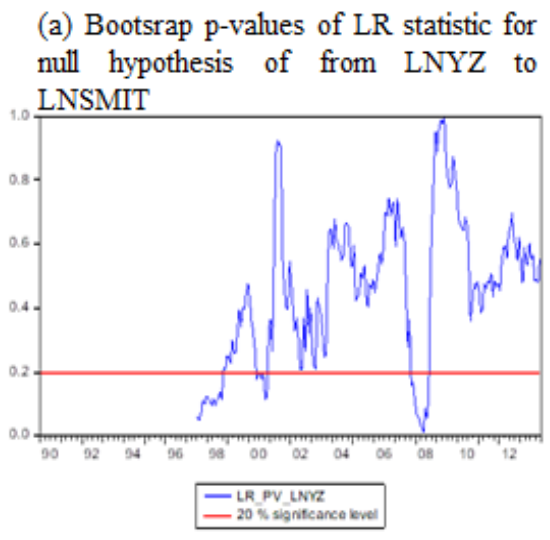

(c) Bootsrap p-values of LR statistic for null hypothesis of from LNSMIT to LNYZ

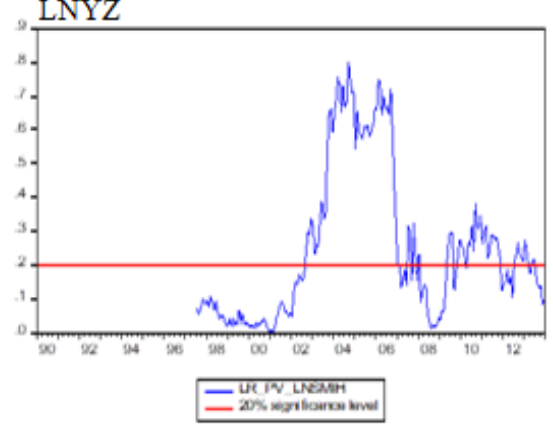

(b) The Effect of LNYZ on LNSMIT, and the Significance of the Coefficients

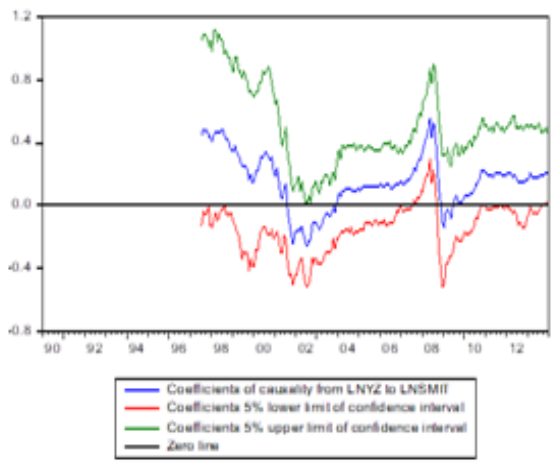

(d) The Effect of LNSMIT on LNYZ, and the Significance of the Coefficients

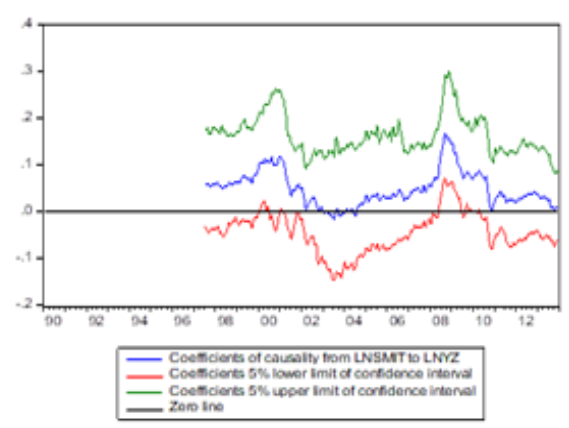

Figure 4. Rolling Window Estimates of Relationships Between LNYZ and LNSMIT

The results indicate the existence of causality from LNYZ to LNSMIT (Figure 4, Panel (a)) in following periods: between 1997M07 and 1998M10, between 2000M05 and 2000M11, Between 2007M10 and 2008M08. As is clearly seen in evidences presented in Figure 4, Panel (b), the all coefficients are significant and showing also that LNYZ has a positive effect on LNSMIT during all causality periods. In Figure 4, Panel (c), we presented the results of timevarying causality tests from LNSMIT to LNYZ. They again provide evidences of causality from LNSMIT to LNYZ during the following periods: between 1997M07 and 2002M08, 2007M01, between 2007M03 and 2007M06, 2007M09, 2007M12, between 2008M02 and 2009M04, between 2009M09 and 2009M10 periods, 2010M04, between 2011M12 and 2012M06, between 2013M03 and 2013M04, between 2013M07 and 2013M12 periods. Based on the Figure 4, Panel (d), we can also conclude that the effects of LNSMIT on LNYZ are significant and positive during whole causality periods.

Figure 5 includes the results of time-varying causality results between LNTIH and LNYZ 
(a) Bootsrap p-values of LR statistic for null hypothesis of from LNYZ to LNTIH

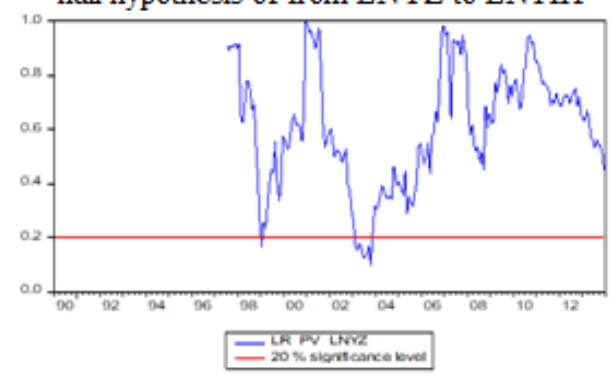

(c) Bootsrap p-values of LR statistic for null hypothesis of from LNTIH to LNYZ

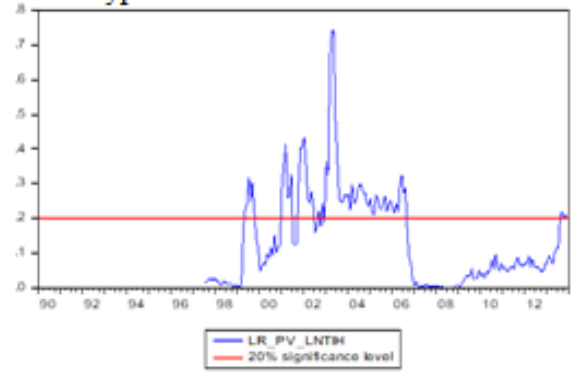

(b) The Effect of LNYZ on LNTIH, and the Significance of the Coefficients

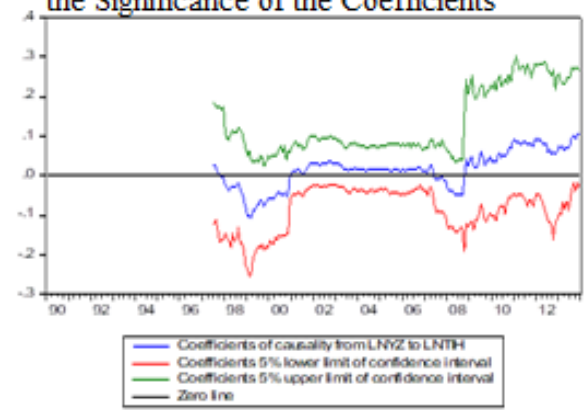

(d) The Effect of LNTIH on LNYZ, and the Significance of the Coefficients

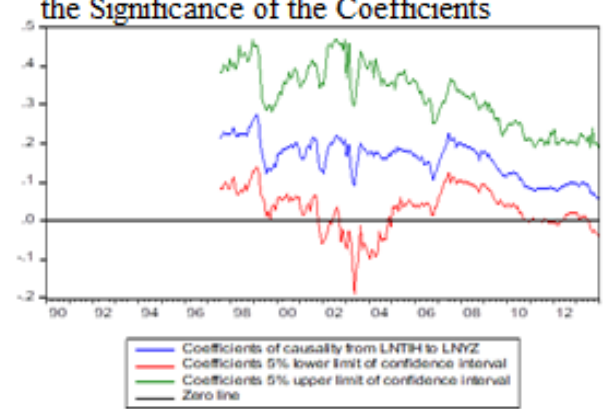

Figure 5. Rolling Window Estimates Of Relationships Between LNYZ and LNTIH.

The evidences that we presented in Figure 5, Panel (a) indicate that there is causality from LNYZ to LNTIH during the periods of 1999M01 and between 2003M02 and 2003M10. Moreover, as Figure 5, Panel (b) shows, the effects of LNYZ on LNTIH are significant and positive during almost all the causality periods except for 1999M01 period. Figure 5, Panel (c) and Figure 5, Panel (d) present the results of causality tests from LNTIH to LNYZ and the effects of LNTIH on LNYZ respectively. The results in Figure 5, Panel (c) demonstrate that in following periods, we reject the null hypothesis of LNTIH does not Granger cause LNYZ: between 1997M07-199M04, between 1999M11 and 2000M12, between 2001M07 and 2001M09, 2002M10, 2002M12, between 2006M09 and 2013M09, 2013M10, and 2013M12. Figure 5, Panel (d) shows that the effect of LNTIH on LNYZ is significant and positive for all causality periods.

Figure 6 includes the time-varying causality test results between LNTIT and LNYZ. 
(a) Bootsrap p-values of LR statistic for null hypothesis of from LNYZ to LNTIT

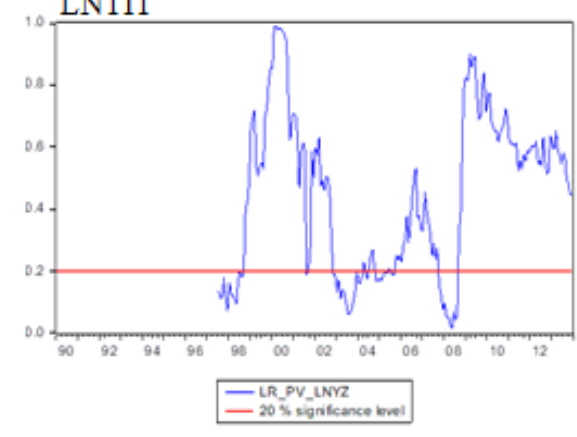

(c) Bootsrap p-values of LR statistic for null hypothesis of from LNTIT to LNYZ

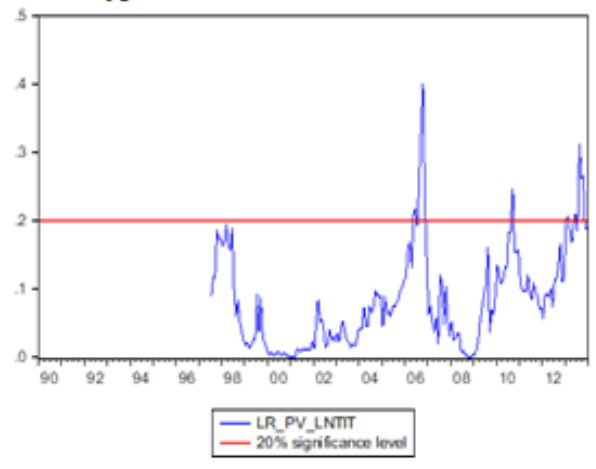

(b)The Effect of LNYZ on LNTIT, and the Significance of the Coefficients

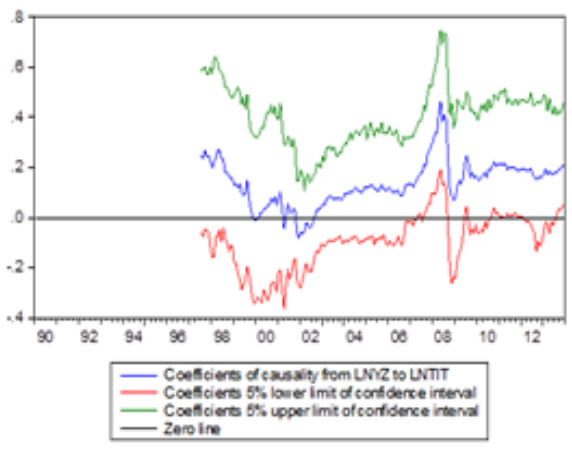

(d) The Effect of LNTIT on LNYZ, and the Significance of the Coefficients

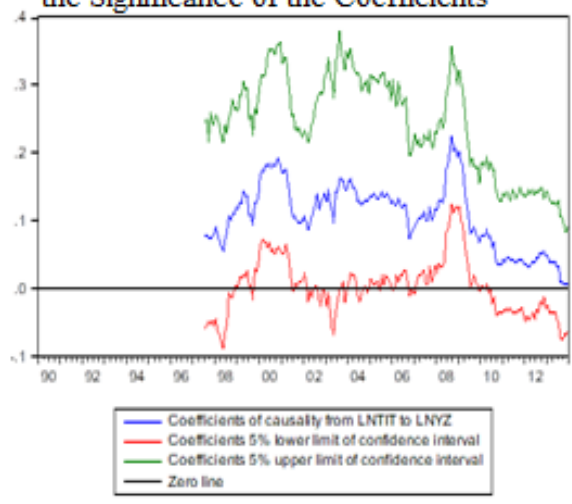

Figure 6. Rolling Window Estimates of Relationships Between LNYZ and LNTIT

Based on Figure 6, Panel (a), we can reject the null hypothesis that LNYZ does not Granger cause LNTIT during the periods of between 1997M07 and 1998M09, 2001M08, between 2002M11 and 2004M03, between 2004M05 and 2004M06, between 2004M11 and 2005M03, 2005M05, between 2005M07 and 2005M08, between 2007M10 and 2008M08. Also, based on the in Figure 6, Panel (b), we can conclude that LNYZ has significant and positive effect on LNTIT during all causality periods. Figure 6, Panel (c) and Figure 6, Panel (d) demonstrate the existence of time-varying causality from LNTIT to LNYZ and the effects of LNTIT on LNYZ respectively. Based on the Figure 6, Panel (c) and Figure 6, Panel (d), we can say that LNTIT Granger cause to LNYZ during the periods below and its effects on LNYZ is significant and positive during all causality periods: between 1997M07 and 2006M04, between 2006M12 and 2010M08, between 2010M10 and 2013M01, between 2013M03 and 2013M05, 2013M07, and between 2013M11 and 2013M12.

\section{CONCLUSION}

In this study, we investigate the causal relations between international tourism demand and components of international trade (exports and imports, intermediate goods import and export, 
and capital goods import and export) in Turkey by Hacker and Hatemi-J Bootstrap TodaYamamoto and Rolling Window Bootstrap Approach to causality. The results of Bootstrap Toda-Yamamoto causality tests indicate that there is bidirectional causality between international tourism demand and overall import. Bootstrap Toda-Yamamoto causality results also provide evidences of unidirectional causality from capital goods import, capital goods export and overall export to international tourism demand.

According to results of time-varying causality tests, there is a negative causality from the international tourism demand to both intermediate goods export and overall export variables for the first and third months of 1999. Likewise, there is negative causality from the international tourism demand to capital goods export during the 1997M08-1997M09. This short period indicate that causal relationships exit at months, which corresponds to low season months of tourism. While 1997M08 period was high season for the tourism sector, 1997M09 marks the beginning of the period that the international tourism demand started to decrease.

The results also show that capital goods export is affecting the international tourism demand longer than that of intermediate goods export and overall export. International tourism demand affects the both intermediate goods export and overall export positively almost during the same time period (2002M10-2004M03/ 2003M02-2003M10). The longest period when capital goods export was affected positively is the 2005M12-2006M11 period. Others are generally affected within one or two months. The impact of international tourism demand on export was shortlived.

Another finding of rolling window approach indicates the less than a year causality from international tourism demand to intermediate goods import and capital goods import. Also, the results of these causality tests show that there is a positive causality from international tourism demand to both intermediate goods import and overall import especially during the crises period, such as 2001 crisis and to both capital goods import and overall import during the periods when the 2008 global crisis was prevailing. Only during the 2001M08-2001M09 periods, the international tourism demand affects intermediate goods import at negative direction. After the 2003M10 period, there is no causality between international tourism demand and intermediate goods import. Furthermore, the periods when international tourism demand caused import and its components generally coincide with the time periods identified as high season for tourism and the season openings. Finally, the periods when such causal relations were present are periods that can be referred as long term, such as, 1997M07-1998M09, 2002M11-2004M03, 2007M102008M08 periods.

Moreover, the results indicate the existence of causality from export and import components to international tourism demand. According to the results, international tourism demand is affected by both export and import components more frequently, and the sign of the causality is usually positive. The intermediate goods export caused long-term positive impact on international tourism demand. For instance, this positive causal relation exists during the 1994M07-1999M04, 1999M11-2000M12, 2006M11-2010M04 periods. There is causality from intermediate goods export to international tourism demand during the 1997M07-1999M03 and 2004M11-2013M12 periods. Also, there is positive causality from overall export to international tourism demand between the 1997M07-1999M04, 1999M11-2000M12, and 2006M09-2013M09 periods. Furthermore, it is observed that there is causality from export components to international tourism demand during longer time periods. 
Similarly, if we examine the periods when there is causality from import components to international tourism demand, we observe that generally there exist positive causal relations over longer periods. For instance, there are long term positive causality from intermediate goods import to international tourism demand during the 199910-2006M05, 2006M12-2009M03 periods. Likewise, it is observed that there is long term positive causality from capital goods import to international tourism demand during the 1997M07-2002M08 and 2008M02-2009M04 periods. The periods when there is causality from overall import to international tourism demand are the long-time periods. There is positive causality from overall import to international tourism demand during longer time periods of 1997M07-2006M04, 2006M12-2010M08 and 2010M012013M01.

These findings of the study demonstrate that there are both short term and long terms causal relations between international tourism demand and international trade. When we look at the time structure of these causal relations, it is fair to conclude that while positive causal relations between international tourism demand and international trade involve the longer time period, the periods when the international tourism demand are caused by international trade are usually short. The international tourism demand has a short-term positive impact on international trade especially during and after the crisis years and the effect of international trade on international tourism are taking place in longer periods. It is because, as is mentioned in Özer (2015), tourism sector continues its inherent activities by increasing import, similar to the industrial sector's heavy reliance on imports, which should be seen as a structural weakness of Turkey's economy relevant to every sector.

The results of the study have some implications for Turkey's economy as well. Since the results of the study overall show that international tourism demand causes increase in overall import, this should be taken as another evidence of how Turkey's economy has become heavily dependent on imports, even in the one of the major sources of foreign exchange earning sectors of tourism. Thus, knowing the fact that import increasing the nature of tourism sector, the policy makers should redesign their national tourism policies taking into account of these major findings of study. In other words, because of unintended effects of development in tourism sector, policy makers in Turkey reconsider the role of tourism sector and tourism policies in their overall development strategy, focusing more on adapting new strategies aiming to increase the sector's contribution to Turkish economy.

\section{REFERENCES}

Arslanturk, Y., Balcilar, M., \& Ozdemir, Z. A. (2011). Time-varying linkages between tourism receipts and economic growth in a small open economy. Economic Modelling, 28(1-2), 664-671. https://doi.org/10.1016/j.econmod.2010.06.003

Bahar, O., \& Baldemir, E. (2008). Uluslararası Ticaret ile Uluslararası Turizm Arasındaki Nedensellik İlişkisi: Türkiye Örneği. Dokuz Eylül Üniversitesi Sosyal Bilimler Enstitüsü Dergisi, 10(4), 97-111.

Balcilar, M., \& Ozdemir, Z. A. (2013). Asymmetric and Time-Varying Causality between Inflation and Inflation Uncertainty in G-7 Countries. Scottish Journal of Political Economy, 60(1), 1-42. https://doi.org/10.1111/sjpe.12000 
Balcilar, M., Ozdemir, Z. A., \& Arslanturk, Y. (2010). Economic growth and energy consumption causal nexus viewed through a bootstrap rolling window. Energy Economics, 32(6), 1398-1410. https://doi.org/10.1016/j.eneco.2010.05.015

Brahmbhatt, J., \& Menezes, R. (2013). On the relation between tourism and trade: A network experiment. 2nd Network Science Workshop (NSW), 74-81. Piscataway, New Jersey: IEEE.

Central Bank of the Republic of Turkey (TCMB). (2014). Electronic Data Delivery System (EVDS). Retrieved December 14, 2014, from https://evds2.tcmb.gov.tr/index.php?

Chaisumpunsakul, W., \& Pholphirul, P. (2018). Does international trade promote international tourism demand? Evidence from Thailand's trading partners. Kasetsart Journal of Social Sciences, 39(3), 393-400. https://doi.org/10.1016/j.kjss.2017.06.007

Egeli, H. A. (1997). Türk turizminin dış ticaret ve sektörlerarası bağlantıları açısından değerlendirilmesi. Ankara Üniversitesi SBF Dergisi, 1. https://doi.org/10.1501/SBFder_0000002001

Fischer, C., \& Gil-Alana, L. A. (2009). The nature of the relationship between international tourism and international trade: the case of German imports of Spanish wine. Applied Economics, 41(11), 1345-1359. https://doi.org/10.1080/00036840601019349

Gautam, V., \& Kg, S. (2012). An Empirical Investigation About Relationship Between International Trade And Tourist Arrival: Evidence From India. Business Excellence and Management, 2(3), 53-62.

Gray, H. P. (1970). International travel-international trade. Lexington: Heath Lexington Books.

Gül, H., \& Özer, M. (2018). Frequency domain causality analysis of tourism and economic activity in Turkey. European Journal of Tourism Research, 19, 86-97. Retrieved from http://ejtr.vumk.eu/index.php/volume1/573-v19rp86

Hacker, R. S., \& Hatemi-J, A. (2006). Tests for causality between integrated variables using asymptotic and bootstrap distributions: theory and application. Applied Economics, 38(13), 1489-1500. https://doi.org/10.1080/00036840500405763

Hanafiah, M., Hafiz, M., Harun, M. F., \& Jamaluddin, M. R. (2011). Trade and Tourism Demand: A Case of Malaysia. International Conference on Business and Economics Research, 1, 1-4. Kuala Lumpur, Malaysia: IACSIT Press.

Kadir, N., \& Jusoff, K. (2010). The Cointegration and Causality Tests for Tourism and Trade in Malaysia. International Journal of Economics and Finance, 2(1). https://doi.org/10.5539/ijef.v2n1p138

Kg, S., Gautam, V., \& Kumar, M. (2011). Analysing the relationships among tourism, trade, and economic growth in Indian perspective. Journal of International Busieness and Economy, 12(1), 1-11. 
Khan, H., \& Lin, C. C. (2002). International trade and tourism: Evidence from cointegration and causality tests by using Singapore data. The 33rd Annual Conference of Travel and Tourism Association (TTRA), 6, 23-26.

Khan, H., Phang, S. -., \& Toh, R. S. (1995). The multiplier effect Singapore's hospitality industry. The Cornell Hotel and Restaurant Administration Quarterly, 36(1), 64-69. https://doi.org/10.1016/S0010-8804(99)80060-3

Khan, H., Toh, R. S., \& Chua, L. (2005). Tourism and Trade: Cointegration and Granger Causality Tests. Journal of Travel Research, 44(2), 171-176. https://doi.org/10.1177/0047287505276607

Kulendran, N., \& Wilson, K. (2000). Is there a relationship between international trade and international travel? Applied Economics, 32(8), 1001-1009. https://doi.org/10.1080/000368400322057

Majewska, J., \& Minska-Struzik, E. (2012). In search of the relationship between international tourism and trade: evidence from Poland. ETSG 2012 Leuven: Fourteenth Annual Conference, 1-26. Retrieved from https://www.etsg.org/ETSG2012/Programme/Papers/447.pdf

Massidda, C., \& Mattana, P. (2013). A SVECM Analysis of the Relationship between International Tourism Arrivals, GDP and Trade in Italy. Journal of Travel Research, 52(1), 93-105. https://doi.org/10.1177/0047287512457262

Nyakabawo, W., Miller, S. M., Balcilar, M., Das, S., \& Gupta, R. (2015). Temporal causality between house prices and output in the US: A bootstrap rolling-window approach. The North American Journal of Economics and Finance, 33, 55-73. https://doi.org/10.1016/j.najef.2015.03.001

Oigenblick, L., \& Kirschenbaum, A. (2002). Tourism and immigration: Comparing alternative approaches. Annals of Tourism Research, 29(4), 1086-1100. https://doi.org/10.1016/S01607383(02)00023-3

Özer, M. (2015). Can Turkey be a good example for the Balkan Nations? The story of illusion of well-being! In X. Richet, H. Hanic, \& Z. Grubisic (Eds.), New Economic Policy Reforms (pp. 15-58). Belgrade: Belgrade Banking Academy.

Polat, E., Türkan, S., \& Günay, S. (2010). Relationship between tourism and trade in Turkey. International Conference On Applied Economics, 591-596. Athens: Department of Economic Sciences, National and Kapodistrian University of Athens.

Santana-Gallego, M., Ledesma-Rodríguez, F. J., \& Pérez-Rodríguez, J. V. (2016). International trade and tourism flows: An extension of the gravity model. Economic Modelling, 52, 1026-1033. https://doi.org/10.1016/j.econmod.2015.10.043

Santana-Gallego, M., Ledesma-Rodríguez, F., \& Pérez-Rodríguez, J. V. (2011). Tourism and trade in OECD countries. A dynamic heterogeneous panel data analysis. Empirical 
Economics, 41(2), 533-554. https://doi.org/10.1007/s00181-011-0477-9

Sarmidi, T., \& Mohd Salleh, N. H. (2011). Dynamic inter-relationship between trade, economic growth and tourism in Malaysia. International Journal of Economics and Management, $5(1), 38-52$.

Seyidoğlu, H. (2007). Uluslarası iktisat-teori, politika ve uygulama. İstanbul: Güzem Can Yayınları.

Shan, J., \& Wilson, K. (2001). Causality between trade and tourism: empirical evidence from China. Applied Economics Letters, 8(4), 279-283. https://doi.org/10.1080/135048501750104114

Socher, K. (1986). Tourism in the theory of international trade and payments. The Tourist Review, 41(3), 24-26. https://doi.org/10.1108/eb057953

Suleiman, N. N., \& Albiman, M. M. (2014). Dynamic relationship between tourism, trade, infrastructure and economic growth: Empirical evidence From Malaysia. Journal of African Studies and Development, 6(3), 49-55. https://doi.org/10.5897/JASD2013.0260

Tang, S., Selvanathan, E. A., \& Selvanathan, S. (2007). The Relationship between Foreign Direct Investment and Tourism: Empirical Evidence from China. Tourism Economics, 13(1), 25-39. https://doi.org/10.5367/000000007779784498

Toda, H. Y., \& Yamamoto, T. (1995). Statistical inference in vector autoregressions with 1231 possibly integrated processes. Journal of Econometrics, 66(1-2), 225-250. https://doi.org/10.1016/0304-4076(94)01616-8

Turkish Statistics Institute. (2014). Retrieved December 14, 2014, from http://www.tuik.gov.tr/

Turner, L. W., \& Witt, S. F. (2001). Factors Influencing Demand for International Tourism: Tourism Demand Analysis Using Structural Equation Modelling, Revisited. Tourism Economics, 7(1), 21-38. https://doi.org/10.5367/000000001101297711

Vellas, F., \& Bécherel, L. (1995). International Tourism: An Economic Perspective. Basingstoke, UK: Macmillan.

World Tourism Organization UNWTO. (2014). UNWTO Tourism Highlights, 2014 Edition. https://doi.org/10.18111/9789284416226 